\title{
French connection: interlocking directorates and ownership network in an insider governance system
}

\author{
Tristan Auvray, University of Paris 13, Sorbonne Paris Cité, CEPN (CNRS, UMR 7234) ${ }^{1}$ \\ Olivier Brossard, Toulouse Institute of Political Studies (IEP) and LEREPS ${ }^{2}$
}

Revue d'économie industrielle, 2016, n 154, p. 177-206. DOI: 10.4000/rei.6377

This is a pre-copyedited, author-produced version of an article published in the Revue

d'économie industrielle and available online at: https://journals.openedition.org/rei/6377

\begin{abstract}
We show that single and multiple overlapping directorships of large French listed corporations are highly explained by their ownership connections. Both large and small stakes, from $20 \%$ to $1 \%$ of cash-flow rights or voting rights, have high explanatory power. We provide evidence also of the existence of a positive relationship between the size of a shareholding and the strength of the correlation between ownership ties and overlapping directorates. Finally, we demonstrate that causality goes from ownership to interlocking directorates, for both unilateral stakes and cross-shareholdings.
\end{abstract}

Keywords: Corporate governance, ownership networks, board interlocks, multiple blockholders.

French connection : réseaux de propriété et d'administrateurs dans un système de gouvernance interne

Résumé : Nous montrons que les liens de propriété entre les grandes sociétés françaises expliquent largement la présence d'administrateurs en commun, unique ou multiples, entre elles. Tant les grandes participations que les petites, de $1 \%$ à $20 \%$ du capital ou des droits de vote, ont un fort pouvoir explicatif. Nous montrons également qu'il existe une relation croissante entre la taille de la participation et la force de la corrélation entre les liens de propriété et l'existence d'administrateurs communs entre les sociétés. Finalement, nous montrons que la causalité va des liens de propriété aux réseaux d’administrateurs, tant pour les participations unilatérales que pour les participations croisées.

Mots clés : gouvernance d'entreprise, réseau de propriété, réseau d’administrateurs, actionnaires multiples.

JEL : G32, G34.

\footnotetext{
${ }^{1}$ tristan.auvray@univ-paris13.fr

2 olivier.brossard@sciencespo-toulouse.fr
} 


\section{Introduction}

Explaining why overlapping directorates ${ }^{3}$ exist is critical to disentangle the conscious or inadvertent reasons of these widespread interorganizational ties (Mizruchi, 1996). While ownership is supposed to give the right to vote for directors, this explanation has notwithstanding rarely been considered. ${ }^{4}$ Only recently Bohman (2012) assesses the probability that two firms are interlocked if they have a common shareholder. He obtains that, when two firms have the same owner, then this owner is likely to appoint the same director to both firms. Nevertheless, studies on the determinants of interlocking directorates seem to ignore that direct and indirect ownership ties between two companies may be both a strong incentive and a simple way to create directorship ties between these corporations.

The purpose of this paper is to assess the strength of the correlation between these financial and human networks. By doing so, we aim to shed light on a dark side of the financial control of corporations that has been somewhat overlooked since Berle and Means (1932). These authors undoubtedly give a very useful and practical definition of financial control. According to them, the main shareholder of a corporation can obtain control by obtaining 20\% of its shares: based on its majority at general meetings due to the confidence or passivity of the other minority shareholders, it can select the directors who then vote for the CEO. The CEO, therefore, can be assumed to represent the main shareholder. ${ }^{5}$ Conversely, when there is no powerful shareholder in the general meeting, managers can usurp power from the board to become a self-perpetuating oligarchy. Since Berle and Means, a corporation without a shareowner owning at least $20 \%$ or $10 \%$ of cash flow rights (CFR) or voting rights (VR) is considered as a management controlled firm. For instance, it is now admitted that in most countries managerial control is a myth because $10 \%$ to $20 \%$ of the VR in a typical listed company are held by the main shareholder (La Porta et al., 1999; Claessens et al., 2000; Barca and Becht, 2001; Faccio and Lang, 2002; Laeven and Levine, 2008; Holderness, 2009; Carney and Child, 2013).

\footnotetext{
${ }^{3}$ A directorate interlock is created between two firms when a director of one of them is also on the board of the other firm: this is the board relationship we explain in this paper.

${ }^{4}$ One noticeable exception is the paper by Berkowitz et al. (1978/1979) who show the strength of ownership and directorship ties inside business group.

${ }^{5}$ This form of control is very strong because majority in general meeting (even with a minority shareholding) provides control of the board (the vote for directors) but also a greater ability to monitor management, and some managerial duties (vote for CEO who controls the corporation on a day-to-day basis, approval of large transactions, and proposal of resolutions in general meeting on payout policy and on selection of new directors).
} 
Nevertheless, this widely accepted definition of control is not exclusive from other forms of influence on the corporation. This is acknowledged by Berle and Means themselves when they provide their practical definition of control (1932, p. 69):

"Control [...], like sovereignty, its counterpart in the political field, is an elusive concept, for power can rarely be sharply segregated or clearly defined. Since direction over the activities of a corporation is exercised through the board of directors, we may say for practical purposes that control lies in the hands of the individual or group who have the actual power to select the board of directors, (or its majority), either by mobilizing the legal right to choose them - 'controlling' a majority of the votes directly or through some legal device - or by exerting pressure which influences their choice.”

In this quote, and more generally in their book, Berle and Means provide three definitions of control. i) A strong form of control is the selection of directors thanks to a majority in general meeting (the well accepted definition). ii) Other forms of pressure on the board exist ("influence”), like the one a banker exerts with or without restrictive covenants. As stressed by Mizruchi (2004), the subsequent literature on interlocking directorates explain how common board membership may be used as a means of external influence, for example by bankers or clients and suppliers. iii) A weaker form of financial control may also occur as shown by the first sentence of this quote which indicates that defining a threshold of $20 \%$ for practical purpose is rather arbitrary. Berle and Means used this cut-off to assert that $44 \%$ of the 200 largest US corporations were controlled by managers. But they also pointed out that, each time a shareholder held between $5 \%$ and $20 \%$ of CFR in their sample, at least one of its representatives was on the board. Only $22 \%$ of their corporations had no shareholder with more than 5\% of CFR. Some authors, like Zeitlin (1974), used these numbers as a proof of the existence of a financial control in the US. ${ }^{6}$

More recently, La Porta et al. (1999, p. 496) acknowledge that, among the largest firms, the percentage of equity needed to actually control them is lower than the conventional thresholds of $20 \%$ or $10 \%$ of cash-flow rights (CFR) or voting rights (VR). For this reason, some authors (e.g. Shleifer and Vishny, 1986; Barca and Becht, 2001) refer to blockholders with at least 5\% shareholdings. According to Zwiebel (1995) a threshold of 1\% is already important because it allows small blockholders to be part of a controlling coalition and to share the partial benefits of control.

\footnotetext{
${ }^{6}$ To be sure, in the remainder of this article we keep the term "control" for the form i) and use the term "influence" for other financial and non-financial forms of pressures on the board (ii and iii).
} 
All these theoretical and empirical studies show that there is still a problem in measuring control with an ad hoc threshold only. In fact control may also appear as a continuum. If it is doubtful that very small shareholdings alone provide control of the board, we should keep in mind, as recognized by the literature, that i) they may reach a majority collectively, or ii) they may be associated to board membership individually. Despite the acknowledgement of the influence of unique or multiple small shareholders on the selection of directors, this financial influence has been disregarded in both corporate governance and interlocking directorate empirical studies.

The contribution of this paper is to show that such an influence exists for a multiplicity of shareholdings among French corporations. We thus analyze the influence on the board composition of multiple shareowners differentiated by their more or less important capital stake. For this purpose, we assess the correlation between a network of ownership ties and a network of overlapping directorates among a set of public corporations. Here, two points are worth mentioning.

First, we do not use an ad hoc legal criterion of CFR or VR to postulate financial influence. Rather, we test a range of thresholds from $1 \%$ to $20 \%$ that may allow a shareholder to obtain a seat on the board, and thereby to take part in board decisions. By analyzing various thresholds, we are able to consider the influence obtained by multiple shareowners of a corporation and not only by the first or the second one. With this method, we show that one of the most influential determinants of the formation of interlocking directorates is ownership linkages. It is important to precise that we do not claim that this correlation is the only symptom of control. However, it means that unique or multiple shareowners are able to influence board selection and appoint directors who will act on their behalf, either to improve their decision-making authority or their monitoring ability, alone or in collusion with entrants or incumbents.

Secondly, focusing on interlocking directorate and financial networks among corporations is particularly relevant for insider governance systems, ${ }^{7}$ which are distinguished by the existence of multiple blockholdings by other financial and non-financial companies

\footnotetext{
${ }^{7}$ In an insider governance system, management and board decisions are controlled by blockholders, while in an outsider governance system market discipline is carried out by outside shareholders through hostile takeovers (see Franks and Mayer, 1997, 2001; Bebchuk and Weisbach, 2010). In other words, according to Tirole (2006), management choices are actively monitored by incumbents in insider systems and by entrants in outsider systems. Moreover, family and corporate blockholders enjoy both the public and private benefits of control in insider systems while outside shareholders derive benefits only in the form of financial returns (Franks et al., 2014). In Europe, as stressed by Faccio and Lang (2002) and Boutillier et al. (2002), ownership is more concentrated in countries like France, Germany and Italy (insider governance systems), than in UK (outsider governance system).
} 
(see e.g. Jenkinson and Ljungqvist, 2001, and Franks and Mayer, 2001, for Germany, and Franks et al., 2014, for Japan). We collect data from several sources to obtain reliable information on board structures and ultimate ownership structures of large French corporations, which are paragons of insider governance systems. Indeed, a dense and complex web of shareholdings exists among French corporations as a result of the waves of privatization that have occurred since the 1980s. The declining government ownership in the main French companies was replaced in the 1990s by multiple core shareholdings between corporations (the so-called noyaux durs) (Morin, 2000; Lantenois and Coriat, 2011). Therefore, we can use these specific French connections to measure the correlation between multiple ownership ties and overlapping directors among firms. Like other shareowners, corporations vote for directors based on their voting rights. Our focus on ownership among French companies is an illustration of the general voting power associated with shareholding. Similar tests should be conducted on other countries with insider governance systems such as Germany and Japan where ownership networks are well-known. ${ }^{8}$ However, France offers the conditions of this experiment and its ownership networks are rarely studied (Morin, 2000) although French corporate governance has been the subject of an increasing number of studies in the financial literature. ${ }^{9}$

Our focus on ownership and directorship ties among corporations is related to studies on this relationship occurring between financial and non-financial companies. Edwards and Nibler (2000) and Gorton and Schmidt (2000) demonstrate that the board structure of German firms is affected by bank shareholdings or by their voting power because they are able to appoint their representatives. Similarly, Franks and Mayer (2001) illustrate the representation of bankers on the boards of firms in which they hold shares or proxy votes while Dittmann et al. (2010) show that in 2000-2005 the sale by a German bank of its holding in a corporation was associated with the removal of its representative from the firm's board. Morck and Nakamura (1999) also provide evidence on this ownership-board structure relationship, among banks and firms in Japan. Even in the US, banks are represented in firms in which they have voting power thanks to their fiduciary activities (Santos and Rumble, 2006). While financial studies tend to focus on the ownership-board link between banks and firms, there is no available evidence on this relationship when it involves other financial firms such as

\footnotetext{
${ }^{8}$ See e.g. Franks and Mayer (1997, 2001), Morin (2000) and Goergen et al. (2008) for France and Germany, and Morck and Nakamura (1999), Aoki et al. (2007) and Franks et al. (2014) for Japan. See also references related to German governance below in the text.

${ }^{9}$ For other references on French corporate governance, see Chikh and Filbien (2011), Ginglinger et al. (2011), Kramarz and Thesmar (2013), Murphy (2005), Bloch and Kremp (2001), and Franks and Mayer (1997).
} 
insurance companies, or when it occurs among non-financial corporations, which are also typical shareholders in insider governance systems. Our contribution evaluates the intensity of this ownership-board correlation considering all possible relationships between banks, insurance companies, and non-financial companies.

Our work also adds to the literature in financial economics which begins to consider interlocking directorates. Overlapping directors among corporations have been receiving increased attention in financial studies, alongside consideration of networks in economics (Jackson, 2008). Renneboog and Zhao (2014), Stuart and Yim (2010) and Chikh and Filbien (2011) show that interlocking directorates facilitate M\&A activities. Cai and Sevilir (2012) find that they explain the positive returns to the acquirer. Interlocks also contribute to diffusing board structure characteristics (Bouwman, 2011) or stock option backdating practices (Bizjak et al., 2009). Renneboog and Zhao (2011), Hwang and Kim (2009), Fich and White (2005) and Hallock (1997) study the effects of interlocks between CEOs, or between CEOs and directors, on CEO pay. Robinson and Stuart (2007) and Lindsey (2008) assess the impact of director networks and equity networks on strategic alliances. However, while ownership connections are potential determinants of interlocking directorates, there are no financial studies on this issue. Khanna and Thomas (2009) and Ferreira and Matos (2012) analyze both interlock and ownership ties, respectively between corporations and between banks and firms, to assess their effect on stock price synchronization or on loan rates, but do not address the causality issue between equity and personal linkages. Our work aims to fill this gap by taking advantage of the panel structure of our data.

In the sociological literature, Comet and Pizarro (2011) compare network measures of capital network and interlocking directorates of French corporations in 2006. Nevertheless, as shown by Mizruchi and Marquis (2006), assessing the correlation of network variables among organizations is more appropriate at a dyadic level of analysis, such as the one we use here (see below, section 1.1). Finally, one article is quite close to our empirical strategy: Bohman (2012), who assesses the probability that two firms are interlocked if they have a common shareholder. Our study controls for this effect. However, shareholders can choose different representatives from their own board. Therefore, we can expect that the probability of being interlocked for two companies will be lower if they have a common shareholder than if one of these companies has equity stakes in the other. We find that interlocking directorates are better explained by ownership ties between two corporations than by the number of common shareholders in these two companies. Moreover, it is worth noting that we have to control for another specific common shareholder which is the French State. As explained by 
François and Lemercier (2014), French state-owned-enterprises have always been well integrated in the French interlocking directorate network because of various factors we include in our study (like size or sector).

The remainder of the paper is organized as follows. Section 1 presents the sample construction, data and empirical issues to be tested. Section 2 describes the econometric method and the main results. Section 3 focuses on robustness tests. Section 4 concludes.

\section{Data and empirical testing issues}

We want to assess the correlation between ownership linkages and board connections after controlling for other possible determinants of interlocking directorates. Shareowners may develop strategies aimed at influencing the composition of the board in order to determine manager selection and influence their subsequent conduct.

\subsection{Sample construction}

The central empirical issue here is to assess the correlation between two kinds of networks: the network created by interlocking directorates and the network formed by companies' ownership linkages. Constructing these networks is therefore the starting point of the sampling approach.

Since gathering reliable information on board composition and ownership linkages requires manually compiling annual reports, there is a limit to the number of firms that can be included in a panel dataset that spans a sufficiently long time period. Moreover, part of the information we need is available only for listed companies; in particular the publication of board structure is not mandatory for non-listed companies. Therefore, we cannot observe the entire network of firms' interlocking directorates and, as usual in structural network analysis, we focus on a relevant sub-network. We selected French companies in the CAC 40, the main Paris Stock Exchange index, which means that our results may be representative only of large listed corporations. ${ }^{10}$ The forty CAC 40 firms are selected, every quarter, from the 100 most traded firms on the Euronext Paris stock exchange. The selection criterion is capitalization provided that shares are liquid enough. Of course, there are entries and exits from the CAC 40

\footnotetext{
${ }^{10}$ However, the number of missing nodes and links in this CAC 40 sub-network is likely to be small: super large companies do not share directors with small firms; and small companies cannot afford to purchase large shareholdings in the massive capitalizations composing the CAC 40. Our econometric results show also that there is a significant homophily effect in the CAC 40 network of interlocking directorates, which shows that CAC 40 firms tend to connect themselves with similar firms.
} 
index over the observation period (1997-2006); the sample is thus composed of 61 companies that were listed in the CAC 40 for at least one quarter between 1997 and 2006 (Table 1). The CAC 40 index is representative of the industries of the SBF 250 index, which is also constructed to be representative of the Paris stock market. ${ }^{11}$

\section{TABLE 1}

The resulting number of firm-years observations is 507. However, because the dependent variable is the probability of having one or more interlocking directors between any possible pair of firms in this sample, the regressions are implemented over all possible dyads between the 61 firms. The 61 firms provide 1,830 dyads $(=61 \times 60 / 2)$ but 20 firms are not listed over the entire 1997-2006 period, either because they entered the French stock exchange after 1997 or because they were delisted before 2006 (Table 1). We therefore implement our regressions on an unbalanced panel of 1,776 undirected firm pairs (or dyads), with 12,611 dyad-year observations (Table 1, and Table 2 Panel B).

\section{TABLE 2}

\subsection{Dependent and independent variables}

\subsubsection{The dependent variable}

It is impossible to measure directly whose interests a director represents, but it can be assumed that, if appointed to the boards of two or more companies, this director will have to consider the interests of each one when exerting her power in another. We therefore construct a count variable equal to the number of interlocks between each firm dyad, and transform it into the following dummy variables: DU_INTERLOCK1=1 when the dyad has one single interlock, and DU_INTERLOCK_MIN2=1 when the dyad has at least two interlocks; the categorical variable INTERLOCKS ranges from 0 to 2 and is equal to 1 if DU_INTERLOCK1=1 and is equal to 2 if DU_INTERLOCK_MIN2=1. Table 2 panel B, describes the evolution of overlapping directors over the period under study. The information on board composition comes from firms' annual reports and financial newspapers and is provided by the Dafsalien database. Board composition of Dafsalien is as of 31 December each year. We systematically checked, and if necessary corrected, the information on whether

\footnotetext{
${ }^{11}$ Representativity tests are available upon request. We implemented them year by year and for 4 sectoral categories in order to have a minimum of 5 observations by year and by category. The sectoral categories are aggregated according to the following 1-digit SIC industrial sectors i) A, B, C, and D (Agriculture, Mining, Construction and Manufacturing); ii) F and G (Wholesale and Retail Trade); iii) E and I (Transportation, Communications, Utilities, and Services; iv) H (Finance, Insurance).
} 
the board chairman was also the firm's CEO. We control for this in the regressions. Board identification is obvious for the one-tier board systems prevailing in most incorporated companies since, in this case, there is only one board. However, some incorporated companies in the sample have a two-tier board system comprising a supervisory board and an executive board, and there are also two companies that are partnerships limited by shares ("Sociétés en commandite par actions") with supervisory boards and one or several managing partners. ${ }^{12}$ For the former companies we consider only the interlocks involving the supervisory board because the executive board is nominated by the supervisory board which is chosen by the shareholders. For the latter, we consider the interlocks involving both the supervisory board and the managing partners.

\subsubsection{Independent variables}

The main independent variables are measures of ownership linkages. Several types of shareholding relationships between CAC 40 companies can generate interlocking directorates between them. We can expect that interlocking directorates between a pair of companies will be more probable if: i) one firm in the dyad holds shares in the other firm; ii) there are crossshareholdings between the firms forming the dyad; iii) a third shareholder (another listed firm or a private owner) holds shares in the two firms of the dyad. Two databases provide CFR for French firms: Thomson One Banker Ownership (TOBO) and Dafsaliens. Dafsaliens also identifies parent companies and business group subsidiaries, which are required to track firms' ultimate owners for each direct shareholding. ${ }^{13}$ We checked the archives of financial newspapers and the information provided on the web site of the French Authority of Financial Markets (AMF) regarding notification of major holdings. When the holding percentage of a particular shareowner differed across sources, we corrected aberrant numbers. We also obtained information on ownership from annual reports in order to check other data sources but also to collect VR figures, which are not reported in TOBO or Dafsaliens. ${ }^{14}$ Where CFR

\footnotetext{
${ }^{12}$ More detailed statistics on the distribution in the dataset of types of companies and board sizes are available on request. The share of two-tier board systems is diminishing from 2003, and the share of companies with separation of board chairman and CEO is growing constantly from 2000. Note also that board size depends on corporate governance laws, and that the NRE law of 2001 obliged French companies to limit the number of board members to 18 within 3 years. This law also reduced the maximum number of a director's simultaneous board memberships, from 8 to 5 .

13 Tracking ultimate owners improves perception of the actual ownership network characterizing the firms in our sample: some CAC 40 firms have no direct ownership linkages but do have indirect ownership ties when we consider the pyramidal chain of their multiple ultimate owners. However, we show in the robustness check section that the use of the ultimate owner methodology does not markedly change the results.

${ }^{14}$ Note also that, because of the 2006 European "transparency" directive, some VR figures are expressed as a percentage of total equity even if some of the shares were deprived of VR because, e.g. they were held by the actual company. In such cases, we recalculated VR on the basis of total outstanding shares.
} 
were available in these two databases but not displayed in annual reports, we assumed that CFR equated with VR. ${ }^{15}$ All regressions presented include ownership linkages computed from CFR; the results were unchanged when we use VR instead of CFR.

We measure the three types of ownership linkages i), ii) and iii) referred to above with the following variables: DU_UNIL_CFR1 is equal to 1 if one of the two firms in the dyad holds a direct share of the stock capital of the other firm; DU_CROSS_CFR $1^{16}$ is equal to 1 if each firm in the dyad holds a share of the other firm's CFR; IDEMOWNER is equal to the number of common private-sector shareholders in the dyad, and DU_STATE is equal to 1 if the French State holds shares in both companies in the dyad. Similarly, we constructed the variable DU_UNIL_VR which is equal to 1 if one of the two firms in the dyad holds a direct share of the VR of the other firm, DU_UNIL_CFR2 which is equal to 1 if one of the two firms in the dyad directly or indirectly holds a share of the CFR of the other firm, and so on. Finally, we split unilateral ownership ties to consider multiple VR or CFR cut-offs. For instance, the variables DU_UNIL_SUP $\alpha_{-}$CFR1 and DU_UNIL_INF $\alpha$ CFR1 refer to the existence of an ownership tie when it brings respectively more than $\alpha \%$ of the CFR and less than $\alpha \%$ of the CFR, where $\alpha$ can take the value of $20,10,5,4,3,2$ or 1 . Table 2 panel $\mathrm{B}$, presents the evolution of DU_UNIL_CFR1 and DU_CROSS_CFR1. We identify 560 unilateral ownership ties among corporations, and 63 cases of cross-ownership.

We also construct control variables for the other possible determinants of interlocking directorates usually considered in the literature. First, in the economic literature, board reputation and directors' expertise are considered important sources of interlocks (e.g. Kaplan and Reishus, 1990; Shivdasani, 1993; Bugeja et al., 2009; Adams et al., 2010): on the demand side of the director labor market, skilled directors are sought-after by managers and shareholders for the supplementary value brought by their expertise; on the offer side, successful directors obtain supplementary directorships in other firms, which implies better compensation and creates an incentive to continue being efficient. As a consequence, firms whose board members are particularly renowned will exhibit more directorate interlocks. We control this effect with two variables for each dyad at time $t$ : $\mathrm{DEGREE}_{i t}$ is the number of outside directorships held by firm i's directors in other firms in the sample, and $\mathrm{DEGREE}_{j t}$ is

\footnotetext{
${ }^{15}$ This assumption is in line with Faccio and Lang's (2000) study which shows that, in 1996, 19.96\% of stock capital was required to obtain a $20 \%$ of VR in French corporations. Nevertheless, as computed for companies of our sample, the first shareowner is required to hold an average of $17.89 \%$ of CFR to obtain $20 \%$ of VR during the sample period. Under French corporate law, double voting can be given to each share belonging to the same shareholder for at least 2 years.

${ }^{16}$ Under French corporate law no shareholding involved in cross-ownership can exceed $10 \%$ of CFR but it can exceed $10 \%$ of VR due to double voting, which however is very rare in our sample (2 cases).
} 
the number of outside directorships held by firm $j$ 's directors in other firms in the sample. Note that DEGREE ${ }_{i t}$ is simply the total number of firm i's interlocks with all the other firms in the sample, and correspondingly for DEGREE $\mathrm{D}_{j \mathrm{t}}$. These two variables are proxies for the reputation of the board of each firm in the dyad $i j$. Since the total number of a firm's interlocks has a greater probability to be important when board size is large, we need to introduce a measure of board size to filter the reputation effect measured by DEGREE $\mathrm{it}_{i t}$ and DEGREE $_{j t}$. We therefore introduce the variable BOARDSIZE which is equal to the sum of the board sizes of both firms in the dyad. In addition, it can be expected that board members of CAC 40 firms possess special expertise on this kind of very large listed firm. This implies that the same small group of persons could compose the talent pool of large capitalizations' boards. It is thus likely that there exists an homophily effect on interlocking directorates: firms that belong to the very selective club of CAC 40 firms tend to use the same talent pool to select their directors, and this professional elite will tend to prefer CAC 40 firms (see, e.g. Mace, 1971; Mizruchi, 1996; Burris, 2005; Conyon and Muldoon, 2006). We assess this homophily effect with the dyadic variable DISTANCETOCAC equal to the absolute value of the difference between the number of years that firm $i$ has been in the CAC 40 over the sampling period, minus the number of years that firm $j$ was in the CAC 40 over the sampling period. ${ }^{17}$ A high DISTANCETOCAC means low degree of homophily, and this variable therefore should have a negative impact on the probability that boards $i$ and $j$ are interlocked.

Another important rationale for interlocking directorates is cost-benefit optimization along various dimensions. Firms have to get access to resources and markets at the lowest costs, and they also have to reduce transaction and information costs as often as possible. Several studies show that sharing directors with suppliers and customers reduces these costs (see, e.g., Booth and Deli, 1996; Pfeffer and Salancik, 2003; Hillman et al., 2000). A similar argument is that firms may plan strategic alliances with suppliers, customers, or competitors operating in the same markets to try to reduce costs or to alleviate competitive pressures. Since strategic alliances often necessitate mutual control, this may generate intra-industry interlocks. Therefore, the probability of interlocking directorates should be higher if firms belong to the same industry sector. ${ }^{18}$ To account for these alliance-related interlocks we create two dummy variables DU_IDEMSIC and DU_FIN2: the first is equal to 1 if the two firms in

\footnotetext{
${ }^{17}$ The time in the CAC 40 is divided by the number of years the firm is present in the sample, for each firm in the dyad.

18 This expected effect could be mitigated by the fact that the benefits of collusion/alliances/market concentrations are inverted U-shaped, that is to say week in competitive markets as well as in very concentrated ones. In further works, we should add more precise measures of the concentration of the markets of the firm dyads to account for this.
} 
the dyad are non-financial firms belonging to the same 2-digit SIC industrial sector; the second is equal to 1 if the two firms are financial companies. Firms also want to secure bank funding at the best possible price. Again, this may produce interlocks because banks send directors to large debtors to reduce problems of asymmetric information, and large borrowers try to be represented on banks' boards to obtain better financing conditions. ${ }^{19}$ However, this may also prevent interlocks because banks are aware of potential conflicts of interests and do not want to become captive monitors (Kroszner and Strahan, 2001). We assess this effect with the dummy DU_FIN1 which is equal to 1 when only one of the two firms is a financial company. $^{20}$

We also need to address the specificity of CEO interlocks. First, there is evidence that CEOs are particularly eager to sit on each other's boards because it provides job security and higher compensation (see e.g., Hallock, 1997; Fich and White, 2005; Kramarz and Thesmar, 2013; Adams et al., 2010). It might be suspected that our results for all interlocks are driven by CEOs interlocks. To check this, we re-run all the regressions with modified dependent variables, excluding CEO interlocks from the count of interlocking directorates (see “Robustness check 1” in next section). While managers' entrenchment strategies may produce CEO interlocks, they do not necessarily favor the formation of interlocks between non-CEO directors: managers may prefer a degree of closure of the firm's governance system to avoid the introduction of external directors that could challenge their decisions. If so, then the more powerful the CEO in the firm the less likely will be the nomination of outside directors keen to monitor his or her actions. Therefore, we can expect a negative correlation between measures of boards' closure and the probability of interlocking directorates. We introduce two variables to address this problem. The first is a measure of board independence, DU_NODUALITY, which is equal to 1 if both firms have adopted the rule that the CEO cannot be the chairman of the board. We expect a positive effect on interlocks probabilities. The second variable is a dyadic measure of ownership concentration, C1MEAN, which is equal to the average voting rights held by the two main shareholders of the two companies. The existence of controlling shareowners should have a negative impact on interlock

\footnotetext{
${ }^{19}$ Evidence on this point is provided e.g. by Morck and Nakamura (1999), Byrd and Mizruchi (2005), Santos and Rumble (2006), Güner et al. (2008), Dittmann et al. (2010), and Ferreira and Matos (2012).

${ }^{20}$ Note that insurance companies are included in the category "financial companies" because, like in Germany, they are important providers of equity for French corporations and this may generate overlapping directors.
} 
probabilities because such large blockholders will not easily accept sharing power with other firms. $^{21}$

\section{Econometric method and results}

Since our main dependent variable, INTERLOCKS, is a dyadic categorical variable, it is natural to use multinomial logit models in this context. The panel structure of our dataset allows us to account for time dependence: in all the regressions, we introduce the nine time dummies corresponding to our 1997-2006 observation period. The panel structure may however generate autocorrelation within each firm dyad, and heteroskedasticity between dyads. That is why we systematically adjust standard errors for clustering at dyad level with the Huber-White correction. There is also a specific autocorrelation issue generated by the dyadic nature of the dependent variable: considering that we have $n$ firms and $n \times(n-1) / 2$ dyads, errors are autocorrelated between dyads because any firm $i$ present in dyad $i j$ is also present in the $n-1$ other possible dyads that include firm $i$. As a consequence, any unobserved characteristic of firm $i$ that would fall into the error term $\varepsilon_{i j}$ could also be present in the errors $\varepsilon_{i k}(\mathrm{k}=1 \ldots(\mathrm{n}-1) ; \mathrm{k} \# \mathrm{j})$ related to firm $i$. The simplest way to address this problem is inspired by gravity models of foreign trade flows (see, e.g., Mátyás, 1997) and consists of introducing weights variables measuring the gravity of each firm in each dyad (see, e.g. Hoekman et al., 2010, who apply the same methodology to scientific collaboration networks). The already described variables DEGREE $_{i t}$ and DEGREE $_{j t}$ which control for reputation effect provide the required gravity measures. We introduce time averaged degrees, AVDEGREE $_{i}$ and AVDEGREE $_{j}$ as firm fixed effects. Since the model includes a distance measure as well (the variable DISTANCETOCAC described above), it is rather similar to a gravity model.

Table 3 displays the results - odd ratios and standard errors - of the multinomial logit regressions of the categorical variable INTERLOCKS on the ownership and control variables described above. The Log Pseudolikelihood and other usual statistics not displayed here show that the overall fit of the model is satisfactory. The Small-Hsiao tests validate the assumption of independence of irrelevant alternatives. All regressions are implemented for the period

\footnotetext{
${ }^{21}$ This might depend on the characteristics of these controlling shareowners. However, because we had to adopt a dyadic approach, it was not possible to introduce a rich array of variables accounting for the characteristics of control investors as done, for example, in La Porta et al. (1999). The difficulty is that, when the two members of a dyad have different qualitative characteristics, it is often impossible to synthesize them in a single dyadic variable. This also explains why we used a reduced number of sectoral variables. We therefore acknowledge that this is a limitation of the present results and we hope to find solutions in further works.
} 
1997-2006 on 1,776 firm dyads, resulting in an unbalanced panel of 12,611 dyad-year observations.

The odds of having one interlocking directorates rather than zero, and at least two interlocking directorates rather than zero, are strongly and positively affected by the three forms of ownership linkages. For example, if one of the two dyad firms holds at least $20 \%$ of the shares of the other firm, the odds of having one interlock rather than zero are multiplied by 10.92 and the odds of having two or more interlocks change by a factor of 92.09 . The factor change coefficients of the ownership variables DU_UNIL, DU_CROSS, DU_UNIL_SUP, and DU_UNIL_INF are much larger than the coefficients of the other significant variables. These results unambiguously evidence that interlocking directorates are strongly correlated to ownership linkages, which can be interpreted as evidence that ownership ties are used to produce monitoring or control linkages. As already discussed, this result counters the view that control or influence is separated from ownership. On this sample of firms, stock owners seem to be able to achieve nominations of directors that will represent their interests. We also obtain that the variable DU_UNIL_INF is significant in all cases, showing that even small shareholdings very much increase the odds of having interlocks. ${ }^{22}$ Also, even if the percentage of shareholdings between the firms in the dyad is very small (Table 3 columns 9 to 12), the coefficients of factor change are more important than the other significant variables. However, the Wald tests displayed under Table 3 (note (5) "UNIL $\geq \alpha$ vs. $\mathrm{UNIL}<\alpha$ ") show that, for all outcomes and all ownership thresholds except the $1 \%$ limit, the coefficients of the dummy measuring large blockholdings are always significantly greater than the coefficients of the dummy measuring small blockholdings. Here again, ownership appears to be an important determinant of monitoring or control ties since the higher is the ownership linkage, the higher will be the ability to affect the course of action of a firm thanks to interlocked directorates.

\section{TABLE 3}

Regarding multiple interlocks, we obtain that the odds of having at least two rather than zero interlocks increase by a factor 11.89 when two firms have a unilateral ownership linkage. This could be interpreted as evidence that some shareowners seek to improve their control power or their monitoring capacity by obtaining more than one devoted director. Moreover, the theory predicts that decision-making authority might be sought by both large and small

\footnotetext{
${ }^{22}$ If we use VR instead of CFR, DU_UNIL_INF no longer explains the existence of one interlock for the 1\% threshold. It suggests that some small shareholders benefit from double voting which allows them to have more than $1 \%$ of the VR. Shareholdings below the $1 \%$ cut-off of CFR but without double voting are not a determinant of single interlocks but still explain multiple interlocks.
} 
blockholders. If these shareholders have a real incentive to seek such control power, then multiple interlocks are likely to be even more strongly correlated to ownership linkages than single interlocks. The Wald tests (notes (3), (4), (6) and (7) to Table 3) provide clear evidence supporting this proposition: all ownership linkage variables tested affect the odds of having multiple interlocks more than those of having a single interlock, and according to the Wald Chi2 statistics, these differences are always significant.

Finally, we can see on Table 3 that cross-ownership has a higher impact on the odds of having multiple interlocking directorates than a unilateral stake. Indeed, this specific corporate ownership lock-in device changes the odds of having at least two interlocks by a factor of 85.34 whereas unreciprocated ownership changes the odds by a factor 11.89. The Wald test (note (4) to Table 3) shows that this difference is significant. Moreover, notice that the difference between unilateral and cross-ownership is not significantly different from zero in the case of a single interlock. Therefore, cross-ownership seems to have a particular influence on multiple overlapping directors, possibly reflecting the control purpose of this ownership lock-in device.

Before commenting on the control variables, it is also useful to notice that common ownership by a third party, measured by the variables IDEMOWNER and DU_STATE, has a much lower effect on board interlocking between a pair of firms than the existence of unilateral or cross-ownership linkages between them.

In relation to the control variables, the factor change coefficients are in line with what is predicted in the literature. First, even after controlling for board size, ${ }^{23}$ our measures of board reputation and competence (DEGREE ${ }_{i t}$ and DEGREE $_{j t}$ ) display coefficients that are significant and greater than 1 . Similarly, the inverted measure of similarity between pairs of firms (DISTANCETOCAC) has the expected significant and less than 1 factor change coefficient. The dummy DU_FIN1 (equal to 1 if one and only one of the two firms is a financial company) has a significant and less than 1 factor change coefficient, which means that pairs of financial and non-financial companies have fewer interlocking directorates than pairs of non-financial companies belonging to different sectors: in line with the argument in Kroszner and Strahan (2001), financial companies seem to avoid interlocking directorates with potential customers because they want to avoid potential conflicts of interests. The idea

\footnotetext{
${ }^{23}$ Note that BOARDSIZE, which is a natural control variable for interlocking directorates, is significant only if the companies have one overlapping director. This effect disappears if the dyad has at least two interlocks. In other words, controlling ties between corporations must be explained by other factors than the natural determinant of interlocking directorates. The effect of BOARDSIZE is significantly different from zero for at least two interlocks only when we remove the board reputation variables DEGREE $i t$ and DEGREE D. $_{j}$
} 
that industry alliances will generate interlocks is not supported in this sample: we find nonsignificant factor change coefficients for the dummy DUIDEMSIC designed to detect alliances between two non-financial firms; the dummy DU_FIN2 constructed to detect alliances between financial firms, shows significantly reduced odds ratios but only for the multiple interlock outcome. Finally, our measures of board openness (C1MEAN and DU_NODUALITY) are not significant.

\section{Robustness checks}

We now have to address several potential shortcomings of the above estimates: 1) the results may be driven by CEO interlocks, and therefore may reflect a managerial entrenchment strategy rather than the possibility for the corporate owner to have directors who will act on its behalf; 2) measures of direct ownership linkages may not capture correctly the reality of ownership connections; 3) the causality between ownership linkages and human linkages (interlocks) may be inverted. In that perspective, we conduct a series of robustness checks that we only present in a summarized way here. The detailed Tables of results are available upon request.

\subsection{Robustness check 1: Are the results driven by CEO interlocks?}

Although our measures of board openness (DU_NODUALITY and C1MEAN) do not have significant effects on the odds of having interlocked directors, which suggests that managerial entrenchment is not driving the results, we check whether removing CEO interlocks changes the findings. The regressions estimated are similar to the above ones, except that the dependent variable is now constructed excluding CEO interlocks. ${ }^{24}$ In the results obtained, the only noticeable modification is that the factor change coefficients of the variable DU_CROSS_CFR1 are no longer significant, which means that the positive impact of cross-shareholdings on interlocking directorates was driven by CEO interlocks. This modification can be interpreted in two ways: 1) either managers use cross-ownership as a means of obtaining a position on each other's boards for entrenchment purpose; or 2) they

\footnotetext{
${ }^{24}$ The count variable INTERLOCKS takes the value zero if CEOs sit on each other’s boards.
} 
promote cross-shareholdings when they sit on each other's boards. ${ }^{25}$ However, the main finding that control is proportional to ownership does not come from CEO interlocks.

\subsection{Robustness check 2: varying the measures of ownership}

\section{linkages}

In the results presented in Table 3, ownership connections are measured on the basis of direct CFR figures. However, pyramid structures ${ }^{26}$ and cross-shareholdings mean that indirect owners may be eligible for board membership either because they ultimately control a direct shareholding or because they contribute to pyramid structure used to control it. Consequently, accounting for these indirect owners may change the correlation between ownership connections and board interlocks. We utilize the information on parent companies and group subsidiaries provided in annual reports and the Dafsaliens database to investigate ownership chains and compute indirect CFR. In that perspective, we make several methodological choices. First, we apply this approach not to VR but to CFR, which means that we implement a linear not a threshold methodology (Vitali et al., 2011). Secondly, while all ultimate controlling owners were identified for each shareholding, they could not be included in the regressions if the companies were not listed on the CAC 40 over the 1997-2006 observation period. The reason for this selection is the dyadic approach employed here: the ownership connections matrix and the interlocking directorates' matrix have to be of same size and composed of the same firms.

For each year we compute a matrix $\mathrm{Y}$ of direct and indirect CFR according to the formula. $^{27}$

\footnotetext{
${ }^{25}$ It is worth noting that Yeo et al. (2003) find a positive relationship between CEOs interlocks and firms' performance in France in 1999, suggesting that cross-ownership and CEOs interlocks were probably not used to increase the consumption of private benefits of control.

${ }^{26}$ In Faccio and Lang's (2002) study, in $15.7 \%$ of cases, French firms with a $20 \%$ controlling shareholder are controlled by a pyramid structure. In our data, this frequency is $22.5 \%$ of firms with a $20 \%$ controlling owner. When the first shareowner holds at least $10 \%$ or $5 \%$ of the VR, there is a pyramid structure in respectively $21.2 \%$ and $26.6 \%$ of cases. The frequency rises to $30.8 \%$ of our year-firm sample if we consider all first shareowners even if they hold less than 5\% of the VR. Consequently, the use of a pyramid by the first shareholder seems to increase with ownership dispersion, suggesting that this structure plays an important role for various capital thresholds of main French corporations.

${ }^{27}$ Another possible approach is to exclude direct participations when the indirect owners of the direct owners benefit from the integrality of the CFR of the latter. In this case, the ownership ties matrix is :
}

$$
\mathrm{Z}=\mathrm{DY}
$$

where $\mathrm{D}=\operatorname{diag}(\mathrm{U} \square \mathrm{S}), \mathrm{U}$ is the unit row vector and $\mathrm{S}=(\mathrm{s})_{1} \quad$ isंद्व, row vector whose elements are: $s_{j}=\sum_{i=1}^{n} x_{i j}$. However we did not adopt this approach because it suppresses direct ownership connections which are shown to 


$$
Y=\sum_{\alpha=1}^{\infty} X^{\alpha}=\left(I_{n}-X\right)^{-1} X
$$

where $\mathrm{X}=\left(x_{i, j}\right)_{1 \leq i, j \leq n} ; x_{i, j}$ is the percentage of direct CFR held by $i$ over $j ; 0 \leq x_{i, j} \leq 1$ and $0 \leq \sum_{i=1}^{n} x_{i, j} \leq 1$. $\alpha$ is the number of links considered in the ownership chain and $\mathrm{I}_{n}$ is the unit matrix of size $n=(\min =142 ; \max =188)$. This formula generates more than 2000 direct and indirect shareholdings between corporations belonging to the CAC 40 index. We consider indirect ownership ties only if they bring at least $0.25 \%$ of the CFR, which is equivalent to an ownership chain with two links of $5 \%$. As a result of this inclusion of indirect ownership ties between the sample firms, the number of unilateral ties increases from 560 to 714, and the number of cross-shareholdings rises from 63 to 84 .

We then re-estimate the multinomial logit equations, replacing the independent variables DU_UNIL_CFR1, DU_CROSS_CFR1, DU_UNIL_SUP_CFR1, DU_UNIL_INF_CFR1 by DU_UNIL_CFR2, DU_CROSS_CRF2, DU_UNIL_SUP_CRF2, DU_UNIL_INF_CRF2 computed with direct and indirect CFR instead of direct CFR. To save space, the results are not displayed here but can be provided upon request. We obtain that the significance of the odds ratios and Wald tests is not affected by this change. The level of some odds ratios is slightly modified but not in a way that changes the interpretation of the results.

\subsection{Robustness check 3: addressing the endogeneity of ownership ties and board connections}

The causality between ownership linkages and human linkages (interlocks) may be inverted because directors sitting on several boards may encourage companies to hold shares in these firms. A simple and preliminary way to address this issue is to lag the ownership linkage variables in the regressions. ${ }^{28}$ We lag the variables DU_UNIL_CFR1, DU_CROSS_CFR1, DU_UNIL_SUP_CFR1, DU_UNIL_INF_CFR1, IDEMOWNER and DU_STATE by one year and three years. Since current interlocks cannot cause past ownership linkages, if the latter have a significant impact on present interlocks this can be interpreted as evidence that there is causality from ownership ties to board linkages, even if the reverse causality is also present at time t. The factor change coefficients of the ownership

\footnotetext{
be effective determinants of board interlocks. Similar methodologies are used and discussed in, e.g., Brioschi et al. (1989), Dietzenbacher and Temurshoev (2008), Vitali et al. (2011), Almeida et al. (2011).

${ }^{28}$ These regressions, not displayed here for space reasons, are available upon request.
} 
connection variables remain large and significant even in the specifications with a three year lag. However, their level is sometimes reduced in comparison to the corresponding coefficients in Table 3. Therefore, even if past ownership ties increase the odds of interlocks, suggesting that at least part of the causality goes from ownership ties to board interlocks, we cannot exclude that the larger contemporaneous correlation is due to a partial inversion of contemporaneous causality.

Thus, we investigate this issue further using instrumented versions of our multinomial logit regressions. Two instrumental variables techniques can be implemented to correct for endogeneity biases in nonlinear models: the two-stage residual inclusion (2SRI) method and the two-stage predictor substitution (2SPS) approach. Both methods use consistent first stage regressions to instrument the variables that are supposed to be endogenous. In 2SPS, the results of the first stage regressions are used to generate predicted values for the endogenous variables. The second-stage regression is conducted after replacing the endogenous variables by their predicted values. In 2SRI, the endogenous variables are not replaced in the secondstage regression. Instead, the first-stage residuals are included as additional regressors. If their coefficients are significant, endogeneity is confirmed. Terza et al. (2008) show that, in contrast to the 2SPS estimator, the 2SRI estimator is consistent for non-linear models such as the multinomial logit we use in this paper whereas the 2SPS estimator can generate substantial bias that is not attenuated by large sample size. We thus chose the 2SRI method for the re-estimation of our model.

The outcomes of the 2SRI re-estimation of the first interlock equation of Table 3 with the variables DU_CROSS_CFR1 considered potentially endogenous suggests rejecting the hypothesis that DU_CROSS_CFR1, DU_UNIL_SUP5_CFR1 and DU_UNIL_INF5_CFR1 are endogenous. We can conclude that the specifications in Table 3 for which we could implement the 2SRI method are not biased by an endogeneity problem. However, we do acknowledge that the large number of observations required to implement this technique with internal instruments and bootstrapped residuals did not allow us to implement the test in the specifications with the largest ownership thresholds (more than $10 \%$ or $20 \%$ of shares).

In summary, this series of robustness tests provides convincing supplementary evidence supporting the results displayed in Table 3: varying ownership measures, removing CEOs interlocks, or addressing potential endogeneity problems does not change our conclusions. However, the exclusion of CEO interlocks from the dependent variable changes results for cross-ownership: the strong correlation between cross-ownership ties and board interlocks is 
driven by CEO interlocks, which can be interpreted as evidence of a managerial entrenchment strategy.

\section{Conclusion}

The aim of this article was to show that the network of overlapping directors and the network of shareholding linkages between large French listed corporations are highly correlated. We show first that both large and small ownership linkages across companies, from $20 \%$ to $1 \%$ of CFR or VR, are strong predictors of overlapping directors among these corporations. The impact of ownership ties on interlocking directorates is clearly stronger than the other potential determinants of overlapping directors we could measure (reputation and competences of board members, homophily, board size and openness, sectoral effects).

This result is congruent with studies on controlling shareholders because we show that the probability that two firms are interlocked is increased more if one of them holds a large stake in the other than if it holds a small stake. Nevertheless, since we also find that small shareholdings can create interlocking directorates our work underlines the need to consider not only the first or the second shareholder but also the entire ownership structure, particularly when it involves other listed companies. A second important contribution is that we show that large and small shareholdings are even more strongly correlated with multiple than single interlocks. We interpret multiple interlocks between two companies as a signal that at least one of the two connected corporations seeks to improve its influence, i.e. its decision-making authority or its monitoring ability. Finally, we show that our results are not biased by endogeneity problems which might be due to causality issues: ownership linkages are the main determinant of interlocking directorates, and not the reverse.

The main implication of these findings is that ownership remains the main way to gain influencing or controlling power even if this is for managerial entrenchment purposes in the case of cross-ownership. Disentangling the positive and negative effects of locking board structures thanks to ownership between corporations is beyond the scope of this paper. Some may argue that it weakens market discipline and competitive constraints while others may claim that it provides the required stability for long term investment. Whatever the purpose of corporate blockholders, it is quite safe to say that the financial density we highlight in this article is a structural feature of French capitalism. Thirty years after the first study on ownership structure in France (Morin, 1974) we still identify a strong ownership network among corporations for the period 1997 to 2006, despite the decline of cross-ownership ties 
that happened during the nineties. We can fairly well suppose that this pattern has not changed significantly after 2007-08 since the financial crisis was associated with a concentration of ownership in many countries, especially in banking. Of course these conclusive statements require more research on both the evolution of the French ownership network and its consequences on corporate governance, competition and investment. 


\section{References}

Adams, R. B., Hermalin, B. E., Weisbach, M. S. (2010), “The Role of Boards of Directors in Corporate Governance: A Conceptual Framework and Survey”, Journal of Economic Literature, 48(1), 58-107.

Almeida, H., Park, S. Y., Subrahmanyam, M. G., Wolfenzon, D. (2011), “The structure and formation of business groups: Evidence from Korean chaebols”, Journal of Financial Economics, 99(2), 447-475.

Aoki, M., Jackson, G., Miyajima, H. (eds.) (2007), Corporate governance in Japan: Institutional change and organizational diversity, New York, Oxford University Press.

Barca, F., Becht, M. (eds.) (2001), The Control of Corporate Europe, New York, Oxford University Press.

Bebchuk, L. A., Weisbach, M. S. (2010), “The State of Corporate Governance Research”, Review of Financial Studies, 23(3), 939-961.

Berle, A. A., Means, G. C. (1932), The modern corporation and private property, New York, The Macmillan Company.

Berkowitz, S. D., Carrington, P. J., Kotowitz, Y., Waverman, L. (1978/1979), “The determination of Enterprise Grouping through Combined Ownership and Directorship ties”, Social Networks, 1, 391-413.

Bizjak, J., Lemmon, M., Whitby, R. (2009), “Option Backdating and Board Interlocks”, Review of Financial Studies, 22(11), 4821-4847.

Bloch, L., Kremp, E. (2001), “Ownership and Voting Power in France”, in F. Barca, M. Becht (eds.), The Control of Corporate Europe, New York, Oxford University Press, 106-127.

Bohman, L. (2012), "Bringing the owners back in: An analysis of a 3-mode interlock network”, Social Networks, 34(2), 275-287.

Booth, J. R., Deli, D. N. (1996), "Factors affecting the number of outside directorships held by CEOs”, Journal of Financial Economics, 40(1), 81-104.

Boutillier, M., Labye, A., Lagoutte, C., Lévy, N., Oheix V. (2002), « Financement et gouvernement des entreprises. Exceptions et convergences européennes », Revue d'économie politique, 112(4), 499-544.

Bouwman, C. H.S. (2011), “Corporate Governance Propagation through Overlapping Directors”, Review of Financial Studies, 24(7), 2358-2394. 
Brioschi, F., Buzzacchi, L., Colombo, M. G. (1989), "Risk capital financing and the separation of ownership and control in business groups”, Journal of Banking \& Finance, 13(4-5), 747-772.

Bugeja, M., Rosa, R. D. S., Lee, A. (2009), “The Impact of Director Reputation and Performance on the Turnover and Board Seats of Target Firm Directors”, Journal of Business Finance \& Accounting, 36(1-2), 185-209.

Burris, V. (2005), “Interlocking Directorates and Political Cohesion among Corporate Elites”, American Journal of Sociology, 111(1), 249-283.

Byrd, D. T., Mizruchi, M. S. (2005), "Bankers on the board and the debt ratio of firms", Journal of Corporate Finance, 11(1-2), 129-173.

Cai, Y., Sevilir, M. (2012), “Board connections and M\&A transactions”, Journal of Financial Economics, 103(2), 327-349.

Carney, R. W., Child, T. B. (2013), "Changes to the ownership and control of East Asian corporations between 1996 and 2008: The primacy of politics”, Journal of Financial Economics, 107(2), 494-513.

Chikh, S., Filbien, J.-Y. (2011), “Acquisitions and CEO power: Evidence from French networks”, Journal of Corporate Finance, 17(5), 1221-1236.

Claessens, S., Djankov, S., Lang, L. H. P. (2000), “The separation of ownership and control in East Asian Corporations”, Journal of Financial Economics, 58(1-2), 81-112.

Comet, C., Pizarro N. (2011), “The cohesion of intercorporate networks in France”, Procedia Social and Behavioral Sciences, 10, 52-61.

Conyon, M., Muldoon, M. R. (2006), “The Small World of Corporate Boards”, Journal of Business Finance \& Accounting, 33(9-10), 1321-1343.

Dietzenbacher, E., Temurshoev, U. (2008), “Ownership relations in the presence of crossshareholding,” Journal of Economics, 95(3), 189-212.

Dittmann, I., Maug, E., Schneider, C. (2010), “Bankers on the Boards of German Firms: What They Do, What They Are Worth, and Why They Are (Still) There,” Review of Finance, 14(1), 35-71.

Edwards, J., Nibler, M. (2000), “Corporate Governance in Germany: The Role of Banks and Ownership Concentration,” Economic Policy, 15(31), 237-267.

Faccio, M., Lang, L. H. P. (2002), “The ultimate ownership of Western European corporations”, Journal of Financial Economics, 65(3), 365-395. 
Ferreira, M. A., Matos, P. (2012), “Universal Banks and Corporate Control: Evidence from the Global Syndicated Loan Market”, Review of Financial Studies, 25(9), 2703-2744.

Fich, E. M., White, L. J. (2005), “Why do CEOs reciprocally sit on each other's boards?”, Journal of Corporate Finance, 11(1-2), 175-195.

François, P., Lemercier, C. (2014), “State or Status Capitalism? Some Insights on French Idiosyncrasis Using an Interlocking Directorates Approach”, Economic Sociology European Electronic Newsletter, 15(2), 17-33.

Franks, J., Mayer, C. (1997), “Corporate Ownership and Control in the U.K., Germany, and France”, Journal of Applied Corporate Finance, 9(4), 30-45.

Franks, J., Mayer, C. (2001), “Ownership and Control of German Corporations”, The Review of Financial Studies, 14(4), 943-977.

Franks, J., Mayer, C., Miyajima, H. (2014), “The Ownerhip of Japanese Corporations in the 20th Century”, Review of Financial Studies, 27(9), 2580-2625.

Ginglinger, E., Megginson, W., Waxin, T. (2011), “Employee ownership, board representation, and corporate financial policies”, Journal of Corporate Finance, 17(4), 868-887.

Goergen, M., Manjon, M. C., Renneboog, L. (2008), "Recent developments in German corporate governance”, International Review of Law and Economics, 28(3), 175-193.

Gorton, G., Schmid, F. A. (2000), “Universal banking and the performance of German firms”, Journal of Financial Economics, 58(1-2), 29-80.

Güner, A. B., Malmendier, U., Tate, G. (2008), “Financial expertise of directors”, Journal of Financial Economics, 88(2), 323-354.

Hallock, K. F. (1997), "Reciprocally Interlocking Boards of Directors and Executive Compensation”, Journal of Financial and Quantitative Analysis, 32(3), 331-344.

Hillman, A. J., Cannella, A. A., Paetzold, R. L. (2000), “The Resource Dependence Role of Corporate Directors: Strategic Adaptation of Board Composition in Response to Environmental Change”, Journal of Management Studies, 37(2), 235-256.

Hoekman, J., Frenken, K., Tijssen, R. J. (2010), "Research collaboration at a distance: Changing spatial patterns of scientific collaboration within Europe”, Research Policy, 39(5), 662-673.

Holderness, C. G. (2009), “The Myth of Diffuse Ownership in the United States”, Review of Financial Studies, 22(4), 1377-1408. 
Hwang, B.-H., Kim, S. (2009), “It pays to have friends”, Journal of Financial Economics, 93(1), 138-158.

Jackson, M. O. (2008), Social and economic networks, Princeton, NJ, Princeton University Press.

Jenkinson, T., Ljungqvist, A. (2001), “The role of hostile stakes in German corporate governance”, Journal of Corporate Finance, 7(4), 397-446.

Kaplan, S. N., Reishus, D. (1990), “Outside directorships and corporate performance”, Journal of Financial Economics, 27(2), 389-410.

Khanna, T., Thomas, C. (2009), “Synchronicity and firm interlocks in an emerging market”, Journal of Financial Economics, 92(2), 182-204.

Kramarz, F., Thesmar, D. (2013), “Social Networks in the Boardroom”, Journal of the European Economic Association, 11(4), 780-807.

Kroszner, R. S., Strahan, P. E. (2001), “Bankers on boards: monitoring, conflicts of interest, and lender liability”, Journal of Financial Economics, 62(3), 415-452.

La Porta, R., Lopez-de-Silanes, F., Shleifer, A. (1999), “Corporate Ownership Around the World”, Journal of Finance, 54(2), 471-517.

Laeven, L., Levine, R. (2008), “Complex Ownership Structures and Corporate Valuations”, Review of Financial Studies, 21(2), 579-604.

Lantenois, C., Coriat, B. (2011), « Investisseurs institutionnels non-résidents, corporate governance et stratégies d'entreprise », Revue d'économie industrielle, 134(2), 51-84.

Lindsey, L. (2008), "Blurring Firm Boundaries: The Role of Venture Capital in Strategic Alliances”, Journal of Finance, 63(3), 1137-1168.

Mace, M. L. (1971), Directors: Myth and Reality, Boston, Harvard Business School Press.

Mátyás, L. (1997), “Proper econometric specification of the gravity model”, The World economy, vol. 20, n³, pp. 363-368.

Mizruchi, M. S., (1996), "What Do Interlocks Do? An Analysis, Critique, and Assessment of Research on Interlocking Directorates,” Annual Review of Sociology, vol. 22, $\mathrm{n}^{\circ} 1$, pp. 271-298.

Mizruchi M. S. (2004), “Berle and Means Revisited: The Governance and Power of Large U.S. Corporations”, Theory and Society, 33(5), 579-617.

Mizruchi, M. S., Marquis, C. (2006), "Egocentric, sociocentric, or dyadic? Identifying the appropriate level of analysis in the study of organizational networks”, Social Networks, 28(3), 187-208. 
Morck, R. K., Nakamura, M. (1999), “Banks and corporate control in Japan”, The Journal of Finance, 54(1), 319-339.

Morin, F. (1974), La structure financière du capitalisme français, Paris, Calmann-Lévy.

Morin, F. (2000), “A Transformation in the French Model of Shareholding and Management”, Economy and Society, 29(1), 36-53.

Murphy, A. (2005), “Corporate Ownership in France: The Importance of History”, in R. K. Morck (ed.), A History of Corporate Governance around the World: Family Business Groups to Professional Managers, Chicago and London, University of Chicago Press, 185-222.

Pfeffer, J., Salancik, G. (2003), The external control of organizations: A resource dependence perspective, Stanford CA, Stanford Business Books.

Renneboog, L., Zhao, Y. (2011), “Us Knows Us in the UK: On Director Networks and Managerial Compensation”, Journal of Corporate Finance, 17(4), 1132-1157.

Renneboog, L., Zhao, Y. (2014), “Director Networks and Takeovers”, Journal of Corporate Finance, 28, 218-234.

Robinson, D. T., Stuart, T. E. (2007), "Network Effects in the Governance of Strategic Alliances”, Journal of Law, Economics \& Organization, 23(1), 242-273.

Santos, J. A. C., Rumble, A. S. (2006), "The American keiretsu and universal banks: Investing, voting and sitting on nonfinancials' corporate boards”, Journal of Financial Economics, 80(2), 419-454.

Shivdasani, A. (1993), "Board composition, ownership structure, and hostile takeovers", Journal of Accounting and Economics, 16(1-3), 167-198.

Shleifer, A., Vishny, R. W. (1986), “Large Shareholders and Corporate Control”, Journal of Political Economy, 94(3), 461-488.

Stuart, T. E., Yim, S. (2010), "Board interlocks and the propensity to be targeted in private equity transactions”, Journal of Financial Economics, 97(1), 174-189.

Terza, J. V., Basu, A., Rathouz, P. J. (2008), “Two-stage residual inclusion estimation: Addressing endogeneity in health econometric modeling”, Journal of Health Economics, 27(3), 531-543.

Tirole, J. (2006), The theory of corporate finance, Princeton, NJ, Princeton University Press.

Vitali, S., Glattfelder, J. B., Battiston, S. (2011), “The Network of Global Corporate Control”, PLoS ONE, 6(10), e25995. 
Yeo, H. J., Pochet, C., Alcouffe, A. (2003), "CEO Reciprocal Interlocks in French Corporations”, Journal of Management \& Governance, 7(1), 87-108.

Zeitlin, M. (1974), “Corporate Ownership and Control: The Large Corporation and the Capitalist Class”, The American Journal of Sociology, 79(5), 1073-1119.

Zwiebel, J. (1995), “Block investment and partial benefits of corporate control”, Review of Economic Studies, 62(2), 161-185.

Table 1. Annual frequency of corporations in the sample

\begin{tabular}{llllllllllllll}
\hline $\begin{array}{l}\text { Number of years in the } \\
\text { sample }\end{array}$ & $\mathbf{1 0}$ & $\mathbf{9}$ & $\mathbf{8}$ & $\mathbf{7}$ & $\mathbf{6}$ & $\mathbf{5}$ & $\mathbf{4}$ & $\mathbf{3}$ & $\mathbf{2}$ & $\mathbf{1}$ & $\begin{array}{c}\text { Total } \\
\text { corp. or } \\
\text { dyad }\end{array}$ & $\begin{array}{c}\text { Total } \\
\text { obs. }\end{array}$ \\
\hline $\begin{array}{l}\text { Number of corporations } \\
\text { that belong to the }\end{array}$ & & & & & & & & & & & & & \\
$\begin{array}{l}\text { CAC40 index at least } \\
\text { one quarter during 1997- } \\
2006\end{array}$ & 41 & 1 & 4 & 2 & 2 & 0 & 2 & 5 & 3 & 1 & 61 & 507 \\
\hline \begin{tabular}{l} 
Number of dyads \\
\hline
\end{tabular} & 820 & 41 & 170 & 89 & 94 & 4 & 96 & 235 & 159 & 68 & 1776 & 12611 \\
\hline
\end{tabular}

Table 2. Evolution of ownership by corporation and by dyad

\begin{tabular}{|c|c|c|c|c|c|c|c|c|c|c|c|c|}
\hline \multirow[t]{2}{*}{ Years } & \multirow[t]{2}{*}{1997} & \multirow[t]{2}{*}{1998} & \multirow[t]{2}{*}{1999} & \multirow[t]{2}{*}{2000} & \multirow[t]{2}{*}{2001} & \multirow[t]{2}{*}{2002} & \multirow{2}{*}{2003} & \multirow{2}{*}{2004} & \multirow[t]{2}{*}{2005} & \multirow[t]{2}{*}{2006} & \multicolumn{2}{|c|}{ 1997-2006 } \\
\hline & & & & & & & & & & & Total & $\%$ \\
\hline \multicolumn{13}{|c|}{ Panel A: \% $\alpha$ of the voting rights ultimately owned by the first owner } \\
\hline $\begin{array}{l}\text { Number of } \\
\text { corporations (n) }\end{array}$ & 50 & 51 & 54 & 51 & 52 & 52 & 50 & 49 & 49 & 49 & 507 & 100,00 \\
\hline$\alpha \geq 50 \%$ & 14 & 16 & 16 & 11 & 12 & 11 & 10 & 8 & 8 & 9 & 115 & 22,68 \\
\hline $20 \% \geq \alpha<50 \%$ & 14 & 13 & 17 & 16 & 16 & 16 & 13 & 16 & 16 & 15 & 152 & 29,98 \\
\hline $10 \% \geq \alpha<20 \%$ & 10 & 11 & 10 & 11 & 10 & 10 & 11 & 10 & 9 & 11 & 103 & 20,32 \\
\hline $5 \% \geq \alpha<10 \%$ & 9 & 8 & 6 & 9 & 10 & 9 & 12 & 10 & 10 & 9 & 92 & 18,15 \\
\hline$\alpha<5 \%$ & 3 & 3 & 5 & 4 & 4 & 6 & 4 & 5 & 6 & 5 & 45 & 8,88 \\
\hline \multicolumn{13}{|c|}{ Panel B: Evolution of main dyadic variables } \\
\hline \multirow[t]{2}{*}{$\begin{array}{l}\text { Number of dyads } \\
(n \times(n-1) / 2)\end{array}$} & 1225 & 1275 & 1431 & 1275 & 1326 & 1326 & 1225 & 1176 & 1176 & 1176 & $\begin{array}{r}1261 \\
1\end{array}$ & 100,00 \\
\hline & \multicolumn{12}{|c|}{ Number of interlocking directorates (in \% of dyads in italic) } \\
\hline \multirow[t]{3}{*}{1 interlock } & 178 & 191 & 214 & 198 & 175 & 171 & 158 & 157 & 152 & 131 & 1725 & 13,68 \\
\hline & 14,5 & 14,9 & 14,9 & 15,5 & 13,2 & 12,9 & 12,9 & 13,3 & 12,9 & 11,1 & & \\
\hline & 3 & 8 & 5 & 3 & 0 & 0 & 0 & 5 & 3 & 4 & & \\
\hline \multirow[t]{3}{*}{ At least 2 interlocks } & 77 & 59 & 60 & 56 & 43 & 37 & 35 & 32 & 25 & 26 & 450 & 3,57 \\
\hline & 6,29 & 4,63 & 4,19 & 4,39 & 3,24 & 2,79 & 2,86 & 2,72 & 2,13 & 2,21 & & \\
\hline & \multicolumn{12}{|c|}{ Number of ownership ties (in \% of dyads in italic) } \\
\hline \multirow[t]{2}{*}{ Unilateral ownership } & 60 & 57 & 67 & 58 & 68 & 60 & 58 & 54 & 47 & 31 & 560 & 4,44 \\
\hline & 4,90 & 4,47 & 4,68 & 4,55 & 5,13 & 4,52 & 4,73 & 4,59 & 4,00 & 2,64 & & \\
\hline \multirow[t]{2}{*}{ Cross-ownership } & 17 & 14 & 8 & 8 & 3 & 3 & 3 & 3 & 2 & 2 & 63 & 0,50 \\
\hline & 1,39 & 1,10 & 0,56 & 0,63 & 0,23 & 0,23 & 0,24 & 0,26 & 0,17 & 0,17 & & \\
\hline
\end{tabular}


Table 3: The impact of direct ownership ties on the odds of having interlocking directorates

Results of multinomial logistic regressions. Observations are pairs of firms $i$ and $j$ (dyads). The dependent variable has three outcomes representing the number of interlocking directorates between $\mathrm{i}$ and $\mathrm{j}: 0$ (there is no interlock between $\mathrm{i}$ and $\mathrm{j}$ ) is the base category; the other outcomes are 1 (firms $\mathrm{i}$ and $\mathrm{j}$ have one interlock) and 2 (firms $\mathrm{i}$ and $\mathrm{j}$ have at least two interlocks). Results are presented for different $\alpha$ thresholds of unilateral ownership between $\mathrm{i}$ and $\mathrm{j}$. $\alpha$ is the percentage of direct cash-flow rights. The two variables varying with this $\alpha$ cut-off are DU_UNIL_SUP_CFR1 and DU_UNIL_INF_CFR1. "DU_" means that the independent variable is a dummy.

UNIL_SUP (UNIL_INF) means that the unilateral ownership is superior (inferior) to the $\alpha$ threshold. Each regression includes 9 time dummies (not displayed).

Coefficients $\beta$ are replaced by factor change coefficients (odds ratios), defined as exp $(\beta)$. Robust standard errors of odds ratios (in parentheses) are adjusted for clustering at dyad level. *,**, and *** indicate significance of the exponentiated coefficients at the $10 \%, 5 \%$, and $1 \%$ levels, respectively.

\begin{tabular}{|c|c|c|c|c|c|c|c|c|c|c|c|c|}
\hline \multirow{2}{*}{$\begin{array}{l}\text { SUP-INF } \alpha \text { cutoff } \\
\text { INTERLOCKS category }\end{array}$} & \multicolumn{2}{|c|}{ (1) All } & \multicolumn{2}{|c|}{ (2) $20 \%$} & \multicolumn{2}{|c|}{ (3) $10 \%$} & \multicolumn{2}{|c|}{ (4) $5 \%$} & \multicolumn{2}{|c|}{ (5) $2 \%$} & \multicolumn{2}{|c|}{ (6) $1 \%$} \\
\hline & 1 & 2 & 1 & 2 & 1 & 2 & 1 & 2 & 1 & 2 & 1 & 2 \\
\hline DU_UNIL_CFR1 & $\begin{array}{c}2.35 * * * \\
(0.53)\end{array}$ & $\begin{array}{c}11.89 * * * \\
(3.87)\end{array}$ & & & & & & & & & & \\
\hline DU_CROSS_CFR1 & $\begin{array}{c}5.74 * * * \\
(3.83)\end{array}$ & $\begin{array}{c}85.34^{* * *} \\
(64.74)\end{array}$ & $\begin{array}{c}5.61^{* * *} \\
(3.71)\end{array}$ & $\begin{array}{c}74.50 * * * \\
(55.66)\end{array}$ & $\begin{array}{c}5.52 * * * \\
(3.64)\end{array}$ & $\begin{array}{c}76.52 * * * \\
(57.13)\end{array}$ & $\begin{array}{c}5.55^{* * *} \\
(3.66)\end{array}$ & $\begin{array}{c}77.65^{* * *} \\
(58.16)\end{array}$ & $\begin{array}{c}5.64^{* * *} \\
(3.74)\end{array}$ & $\begin{array}{c}81.07 * * * \\
(61.15)\end{array}$ & $\begin{array}{c}5.74^{* * *} \\
(3.83)\end{array}$ & $\begin{array}{c}84.20 * * * \\
(63.73)\end{array}$ \\
\hline DU_UNIL_SUP_CFR1 & & & $\begin{array}{c}10.92^{* * *} \\
(5.57)\end{array}$ & $\begin{array}{c}92.09 * * * \\
(66.59)\end{array}$ & $\begin{array}{c}13.35^{* * *} \\
(6.28)\end{array}$ & $\begin{array}{c}60.99 * * * \\
(41.21)\end{array}$ & $\begin{array}{c}8.84^{* * *} \\
(4.12)\end{array}$ & $\begin{array}{c}39.45^{* * *} \\
(24.02)\end{array}$ & $\begin{array}{c}3.75^{* * *} \\
(1.23)\end{array}$ & $\begin{array}{c}19.34^{* * *} \\
(7.98)\end{array}$ & $\begin{array}{c}2.34^{* * *} \\
(0.59)\end{array}$ & $\begin{array}{c}12.49^{* * *} \\
(4.31)\end{array}$ \\
\hline DU_UNIL_INF_CFR1 & & & $\begin{array}{c}1.98 * * * \\
(0.47)\end{array}$ & $\begin{array}{c}8.03^{* * * *} \\
(2.41)\end{array}$ & $\begin{array}{l}1.76^{* *} \\
(0.41)\end{array}$ & $\begin{array}{c}8.20 * * * \\
(2.55)\end{array}$ & $\begin{array}{l}1.69 * * \\
(0.41)\end{array}$ & $\begin{array}{c}7.98 * * * \\
(2.51)\end{array}$ & $\begin{array}{l}1.63 * * \\
(0.41)\end{array}$ & $\begin{array}{c}7.51^{* * * *} \\
(2.61)\end{array}$ & $\begin{array}{c}2.35^{* *} \\
(0.86)\end{array}$ & $\begin{array}{c}9.37 * * * \\
(4.41)\end{array}$ \\
\hline IDEMOWNER & $\begin{array}{l}1.22 * * \\
(0.11)\end{array}$ & $\begin{array}{c}1.53 * * * \\
(0.24)\end{array}$ & $\begin{array}{l}1.23 * * \\
(0.11)\end{array}$ & $\begin{array}{c}1.55^{* * *} \\
(0.24)\end{array}$ & $\begin{array}{l}1.23 * * \\
(0.11)\end{array}$ & $\begin{array}{c}1.54 * * * \\
(0.24)\end{array}$ & $\begin{array}{l}1.22 * * \\
(0.11)\end{array}$ & $\begin{array}{c}1.53^{* * * *} \\
(0.24)\end{array}$ & $\begin{array}{l}1.22 * * \\
(0.11)\end{array}$ & $\begin{array}{c}1.53^{* * * *} \\
(0.24)\end{array}$ & $\begin{array}{l}1.22 * * \\
(0.11)\end{array}$ & $\begin{array}{c}1.53^{* * *} \\
(0.24)\end{array}$ \\
\hline DU_STATE & $\begin{array}{l}1.37 * * \\
(0.17)\end{array}$ & $\begin{array}{l}1.22 \\
(0.34)\end{array}$ & $\begin{array}{l}1.37 * * \\
(0.17)\end{array}$ & $\begin{array}{l}1.22 \\
(0.35)\end{array}$ & $\begin{array}{l}1.37 * * \\
(0.17)\end{array}$ & $\begin{array}{l}1.24 \\
(0.35)\end{array}$ & $\begin{array}{l}1.37 * * \\
(0.17)\end{array}$ & $\begin{array}{c}1.22 \\
(0.34)\end{array}$ & $\begin{array}{l}1.37^{* *} \\
(0.17)\end{array}$ & $\begin{array}{l}1.23 \\
(0.34)\end{array}$ & $\begin{array}{l}1.37 * * \\
(0.17)\end{array}$ & $\begin{array}{l}1.23 \\
(0.34)\end{array}$ \\
\hline C1MEAN & $\begin{array}{l}1.00 \\
(0.00)\end{array}$ & $\begin{array}{l}1.01 \\
(0.01)\end{array}$ & $\begin{array}{l}1.00 \\
(0.00)\end{array}$ & $\begin{array}{l}1.01 \\
(0.01)\end{array}$ & $\begin{array}{l}1.00 \\
(0.00)\end{array}$ & $\begin{array}{l}1.01 \\
(0.01)\end{array}$ & $\begin{array}{l}1.00 \\
(0.00)\end{array}$ & $\begin{array}{l}1.01 \\
(0.01)\end{array}$ & $\begin{array}{l}1.00 \\
(0.00)\end{array}$ & $\begin{array}{l}1.01 \\
(0.01)\end{array}$ & $\begin{array}{l}1.00 \\
(0.00)\end{array}$ & $\begin{array}{l}1.01 \\
(0.01)\end{array}$ \\
\hline BOARDSIZE & $\begin{array}{l}1.03 * * \\
(0.01)\end{array}$ & $\begin{array}{l}1.02 \\
(0.03)\end{array}$ & $\begin{array}{l}1.03 * * \\
(0.01)\end{array}$ & $\begin{array}{l}1.02 \\
(0.03)\end{array}$ & $\begin{array}{l}1.03 * * \\
(0.01)\end{array}$ & $\begin{array}{l}1.02 \\
(0.03)\end{array}$ & $\begin{array}{l}1.03 * * \\
(0.01)\end{array}$ & $\begin{array}{l}1.02 \\
(0.03)\end{array}$ & $\begin{array}{l}1.03^{* *} \\
(0.01)\end{array}$ & $\begin{array}{c}1.02 \\
(0.03)\end{array}$ & $\begin{array}{l}1.03^{* *} \\
(0.01)\end{array}$ & $\begin{array}{l}1.02 \\
(0.03)\end{array}$ \\
\hline DU_NODUALITY & $\begin{array}{l}1.23 \\
(0.20)\end{array}$ & $\begin{array}{l}1.28 \\
(0.49)\end{array}$ & $\begin{array}{c}1.24 \\
(0.20)\end{array}$ & $\begin{array}{l}1.31 \\
(0.49)\end{array}$ & $\begin{array}{c}1.24 \\
(0.20)\end{array}$ & $\begin{array}{l}1.31 \\
(0.49)\end{array}$ & $\begin{array}{l}1.24 \\
(0.20)\end{array}$ & $\begin{array}{l}1.30 \\
(0.49)\end{array}$ & $\begin{array}{l}1.23 \\
(0.20)\end{array}$ & $\begin{array}{l}1.28 \\
(0.48)\end{array}$ & $\begin{array}{l}1.24 \\
(0.20)\end{array}$ & $\begin{array}{l}1.28 \\
(0.49)\end{array}$ \\
\hline DU_FIN1 & $\begin{array}{c}0.72 * * \\
(0.10)\end{array}$ & $\begin{array}{c}0.31^{* * *} \\
(0.10)\end{array}$ & $\begin{array}{c}0.74 * * \\
(0.11)\end{array}$ & $\begin{array}{c}0.38^{* * *} \\
(0.11)\end{array}$ & $\begin{array}{l}0.76^{*} \\
(0.11)\end{array}$ & $\begin{array}{c}0.36^{* * *} * \\
(0.10)\end{array}$ & $\begin{array}{l}0.76^{*} \\
(0.11)\end{array}$ & $\begin{array}{c}0.36^{* * * *} \\
(0.10)\end{array}$ & $\begin{array}{c}0.73^{* *} \\
(0.10)\end{array}$ & $\begin{array}{c}0.34^{* * *} \\
(0.10)\end{array}$ & $\begin{array}{c}0.72 * * \\
(0.10)\end{array}$ & $\begin{array}{c}0.32 * * * \\
(0.10)\end{array}$ \\
\hline DU_FIN2 & $\begin{array}{c}0.69 \\
(0.32)\end{array}$ & $\begin{array}{c}0.20^{* *} \\
(0.16)\end{array}$ & $\begin{array}{c}0.72 \\
(0.33)\end{array}$ & $\begin{array}{l}0.24^{*} \\
(0.19)\end{array}$ & $\begin{array}{c}0.70 \\
(0.32)\end{array}$ & $\begin{array}{l}0.22 * \\
(0.17)\end{array}$ & $\begin{array}{c}0.67 \\
(0.31)\end{array}$ & $\begin{array}{c}0.20 * * \\
(0.16)\end{array}$ & $\begin{array}{c}0.67 \\
(0.31)\end{array}$ & $\begin{array}{c}0.20^{* *} \\
(0.16)\end{array}$ & $\begin{array}{c}0.69 \\
(0.32)\end{array}$ & $\begin{array}{c}0.20^{* *} \\
(0.16)\end{array}$ \\
\hline DU_IDEMSIC & $\begin{array}{c}0.93 \\
(0.29)\end{array}$ & $\begin{array}{l}2.98^{*} \\
(1.76)\end{array}$ & $\begin{array}{c}0.90 \\
(0.29)\end{array}$ & $\begin{array}{c}2.70 \\
(1.73)\end{array}$ & $\begin{array}{c}0.84 \\
(0.27)\end{array}$ & $\begin{array}{c}2.49 \\
(1.69)\end{array}$ & $\begin{array}{c}0.86 \\
(0.27)\end{array}$ & $\begin{array}{c}2.59 \\
(1.70)\end{array}$ & $\begin{array}{c}0.91 \\
(0.28)\end{array}$ & $\begin{array}{l}2.78^{*} \\
(1.72)\end{array}$ & $\begin{array}{c}0.94 \\
(0.29)\end{array}$ & $\begin{array}{l}2.96^{*} \\
(1.76)\end{array}$ \\
\hline DISTANCETOCAC & $\begin{array}{l}0.60 * * \\
(0.14)\end{array}$ & $\begin{array}{l}0.45^{*} \\
(0.20)\end{array}$ & $\begin{array}{l}0.58 * * \\
(0.13)\end{array}$ & $\begin{array}{c}0.37 * * \\
(0.18)\end{array}$ & $\begin{array}{l}0.58 * * \\
(0.13)\end{array}$ & $\begin{array}{l}0.41^{*} \\
(0.19)\end{array}$ & $\begin{array}{c}0.58 * * \\
(0.13)\end{array}$ & $\begin{array}{l}0.42^{*} \\
(0.19)\end{array}$ & $\begin{array}{c}0.59 * * \\
(0.13)\end{array}$ & $\begin{array}{l}0.42^{*} \\
(0.19)\end{array}$ & $\begin{array}{c}0.60 * * \\
(0.14)\end{array}$ & $\begin{array}{l}0.44^{*} \\
(0.20)\end{array}$ \\
\hline DEGREE $_{i t}$ & $\begin{array}{c}1.10 * * * \\
(0.01)\end{array}$ & $\begin{array}{c}1.11^{* * *} \\
(0.02)\end{array}$ & $\begin{array}{c}1.10^{* * * *} \\
(0.01)\end{array}$ & $\begin{array}{c}1.11^{* * * *} \\
(0.02)\end{array}$ & $\begin{array}{c}1.10^{* * * *} \\
(0.01)\end{array}$ & $\begin{array}{c}1.10^{* * * *} \\
(0.02)\end{array}$ & $\begin{array}{c}1.10^{* * *} \\
(0.01)\end{array}$ & $\begin{array}{c}1.11^{* * * *} \\
(0.02)\end{array}$ & $\begin{array}{c}1.10^{* * *} \\
(0.01)\end{array}$ & $\begin{array}{c}1.10^{* * * *} \\
(0.02)\end{array}$ & $\begin{array}{c}1.10^{* * *} \\
(0.01)\end{array}$ & $\begin{array}{c}1.11^{* * *} \\
(0.02)\end{array}$ \\
\hline
\end{tabular}




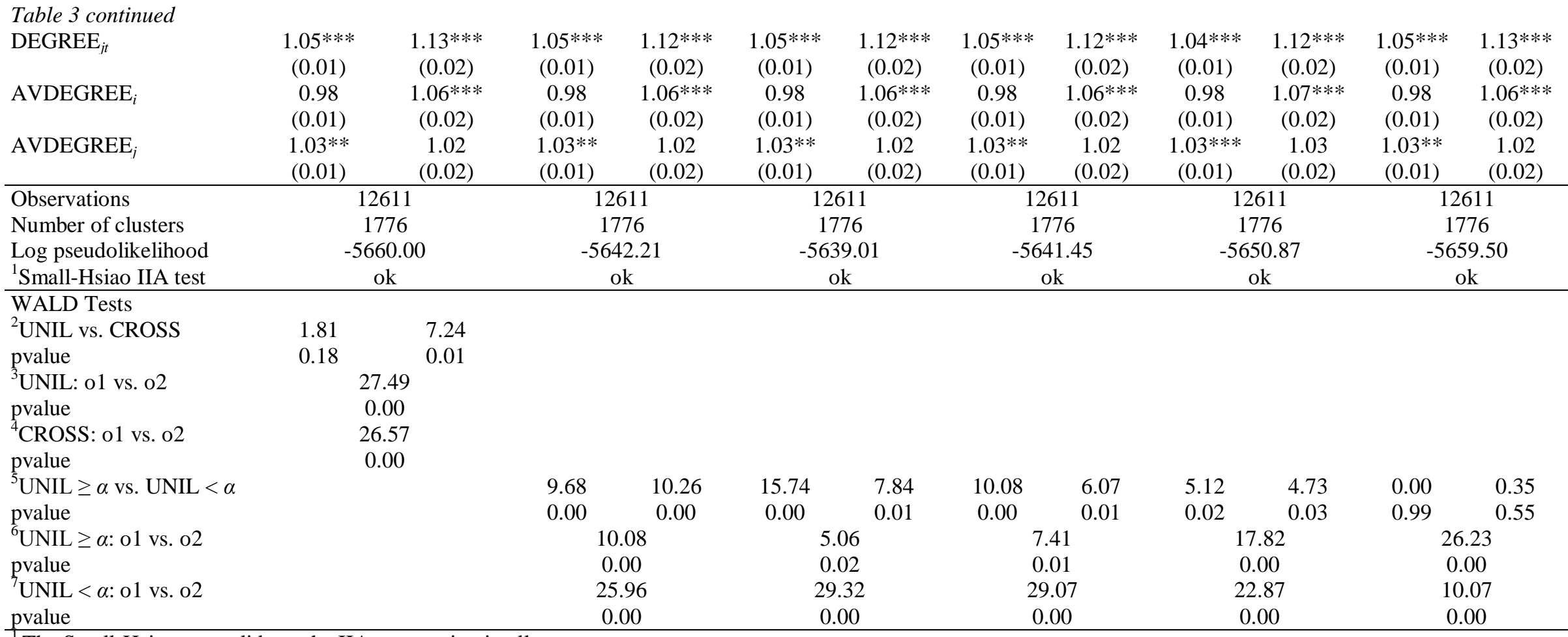

The Small-Hsiao test validates the IIA assumption in all cases.

${ }^{2}$ Chi2 statistic for the hypothesis that the difference of the $\beta$ coefficients of DU_UNIL_CFR1 and DU_CROSS_CFR1 is zero.

${ }^{3}$ Chi2 statistic for the hypothesis that the difference of the DU_UNIL_CFR1 $\beta$ coefficients of outcome 1 and outcome 2 is zero.

${ }^{4}$ Chi2 statistic for the hypothesis that the difference of the DU_CROSS_CFR1 $\beta$ coefficients of outcome 1 and outcome 2 is zero.

${ }^{5}$ Chi2 statistic for the hypothesis that the difference of the $\beta$ coefficients of DU_UNIL_SUP_CFR1 and DU_UNIL_INF_CFR1 is zero.

${ }^{6}$ Chi2 statistic for the hypothesis that the difference of the DU_UNIL_SUP_CFR1 $\beta$ coefficients of outcome 1 and outcome 2 is zero.

${ }^{7}$ Chi2 statistic for the hypothesis that the difference of the DU_UNIL_INF_CFR1 $\beta$ coefficients of outcome 1 and outcome 2 is zero. 